\title{
Profil Asam Lemak Jenuh Dan Tak Jenuh serta Kandungan Kolesterol Nugget Daging Kelinci New Zealand White (Oryctolagus cuniculus)
}

\author{
Nia Fitriani Aisyah ${ }^{1}$, Nisa Aisyah ${ }^{1}$, Titis Sari Kusuma ${ }^{1}$ Rahma Micho Widyanto $^{1 *}$ \\ ${ }^{1}$ Program Studi Ilmu Gizi, Fakultas Kedokteran, Universitas Brawijaya, \\ Jl.Veteran, Malang, 65145
}

Penulis untuk Korespondensi/E-mail: micho@ub.c.id

\begin{abstract}
Abstrak - Daging kelinci merupakan salah satu jenis daging yang memiliki potensi tinggi dalam pemenuhan konsumsi daging bagi masyarakat. Daging kelinci memiliki beberapa keistimewaan yaitu kandungan asam lemak jenuh dan kolesterol yang rendah serta kandungan asam lemak tak jenuh yang tinggi. Salah satu produk olahan daging kelinci yang bisa diperkenalkan kepada masyarakat adalah nugget daging kelinci yang diharapkan dapat memiliki manfaat kesehatan untuk menurunkan risiko Penyakit Jantung Koroner. Tujuan dari penelitian ini adalah untuk mengetahui profil asam lemak jenuh dan tak jenuh serta kandungan kolesterol pada nugget daging kelinci New Zealand White (Oryctolagus cuniculus). Desain penelitian yang digunakan adalah deskriptif eksploratif dengan 3 kali pengulangan menggunakan resep yang sama. Profil asam lemak dan kandungan kolesterol diuji menggunakan metode kromatografi gas. Hasil penelitian menunjukkan bahwa nugget daging kelinci mengandung 17 profil asam lemak jenuh dengan kandungan tertinggi yaitu asam palmitat, disusul oleh asam behenik, asam lignoserik, asam miristat, dan asam margarik. Kemudian, untuk profil asam lemak tak jenuh pada nugget daging kelinci mengandung 9 profil asam lemak tak jenuh tunggal dengan kandungan tertinggi yaitu asam oleat, disusul oleh asam nervonat, asam erukat, asam trans 9 elaidat, dan asam palmitoleat. Untuk asam lemak tak jenuh ganda terdiri dari 11 profil asam lemak dengan kandungan yang tertinggi yaitu asam linoleat, disusul oleh DHA, dan EPA. Selain asam lemak, nugget daging kelinci juga mengandung kolesterol sebesar 15,12 mg/100 g. Dengan kandungan gizi yang baik, nugget daging kelinci diharapkan dapat menjadi alternatif makanan untuk menurunkan risiko Penyakit Jantung Koroner.
\end{abstract}

Abstract - Rabbit meat is one type of meat that has high potential in fulfilling meat consumption for the community. Rabbit meat has several advantages is low saturated fatty acid content and cholesterol and high unsaturated fatty acids. One of the processed products of rabbit meat that can be introduced to the community is rabbit meat nuggets that expected has health benefits it can reduce the risk of coronary heart disease. The purpose of this study was to know profile of saturated fatty acids, unsaturated fatty acids, and cholesterol content on rabbitmeat nuggetsof NewZealandWhite (Oryctolagus cuniculus). The research design used was descriptive exploratory with 3 repetitions using the same recipe. Profiles of fatty acids and cholesterol content were tested using gas chromatography method. The results showed that rabbit meat nuggets contained 17 profiles of saturated fatty acids with the highest content of palmitic acid, followed by behenic acid, lignoseric acid, myristic acid, and margaric acid. Then, for unsaturated fatty acid profiles on rabbit meat nuggets containing 9 profiles of monounsaturated fatty acids with the highest content, oleic acid, followed by nervonic acid, erucic acid, elaidat trans acid 9, and palmitoleic acid. Polyunsaturated fatty acids consist of 11 fatty acid profiles with the highest content, linoleic acid, followed by DHA, and EPA. Besides fatty acids, rabbit meat nuggets also contain cholesterol of $15,12 \mathrm{mg} / 100 \mathrm{~g}$. With a good nutrition content, rabbit meat nuggets are expected to be an alternative food to reduce the risk of coronary heart disease.

Keywords - Cholesterol, Profile of saturated and unsaturated fatty acids, Rabbit meat nuggets 


\section{PENDAHULUAN}

$\mathrm{D}$ aging kelinci merupakan salah satu jenis daging yang memiliki potensi tinggi dalam pemenuhan konsumsi daging bagi masyarakat. Namun, daging kelinci belum populer disebabkan karena faktor kebiasaan dan efek psikologis yang menganggap kelinci sebagai hewan kesayangan [1]. Daging kelinci memiliki serat halus dan warna sedikit pucat dengan persentase karkas mencapai $50 \%$ [2]. Produksi daging kelinci di Indonesia pada tahun 2016, 2017, dan 2018 mencapai angka 458 ton, 479 ton, dan 417 ton (hasil sementara pada tahun tersebut) [3].

Beberapa keistimewaan yang dimiliki daging kelinci diantaranya adalah kadar protein yang tinggi (25\%), lemak rendah (4\%), asam lemak tak jenuh yang tinggi $(60,5 \%)$, asam lemak jenuh rendah $(38 \%)$, serta kolesterol yang rendah (56,4 mg) [1][4][5][6]. Kombinasi antara kandungan asam lemak tak jenuh yang tinggi serta asam lemak jenuh dan kolesterol yang rendah menjadikannya baik dikonsumsi untuk kesehatan. Salah satu jenis kelinci yang saat ini banyak dikembangkan di Indonesia adalah kelinci New Zealand White karena memiliki tingkat pertumbuhan yang cepat [7].

Upaya yang dapat dilakukan untuk memperkenalkan daging kelinci New Zealand White kepada masyarakat adalah dengan melakukan diversifikasi pangan menjadi produk olahan bernilai tinggi, salah satunya adalah nugget daging kelinci. Nugget merupakan salah satu pangan olahan daging yang tergolong restructure meat, yaitu menyatukan kembali potongan daging kecil menjadi satu bentuk olahan yang kompak [6].

Nugget diolah dengan cara digiling, diberi bumbu, dicampur dengan bahan pengikat, dicetak menjadi bentuk tertentu, dilumuri dengan tepung roti kemudian digoreng setengah matang dan dibekukan [8]. Nugget daging kelinci mengandung protein $10,71 \%$, lemak total $3,34 \%$, karbohidrat $30,29 \%$ serta komposisi asam lemak jenuh dan tak jenuh masing-masing sebesar $1,16 \%$ dan $1,74 \%$ [9].

Adanya produk pangan berupa nugget daging kelinci ini, diharapkan dapat memiliki manfaat kesehatan, salah satunya untuk menurunkan risiko terjadinya Penyakit Jantung Koroner/PJK. Pada tahun 2012, PJK menduduki peringkat pertama penyumbang angka kematian di Indonesia [10]. Prevalensi PJK di Indonesia adalah 2,0\% [11].
Penyebab utama terjadinya PJK adalah diet yang tidak sehat seperti konsumsi makanan tinggi lemak jenuh dan kolesterol [12]. Dikarenakan berbagai manfaat yang dimiliki daging kelinci, maka peneliti tertarik melakukan penelitian terkait profil asam lemak jenuh dan tak jenuh serta kandungan kolesterol pada produk olahan daging kelinci berupa nugget.

Tujuan dari penelitian ini adalah untuk mengetahui profil asam lemak jenuh dan tak jenuh serta kandungan kolesterol pada nugget daging kelinci New Zealand White (Oryctolagus cuniculus) yang diharapkan dapat menjadi informasi dasar mengenai kandungan nilai gizi dari nugget daging kelinci sehingga mampu meningkatkan pemanfaatan potensi daging kelinci sebagai produk olahan daging.

\section{METODE PENELITIAN}

Pembuatan nugget daging kelinci dilakukan di Laboratorium Penyelenggaran Makanan, Fakultas Kedokteran, Universitas Brawijaya Malang. Kemudian, untuk pengemasan vakum nugget dilakukan di Laboratorium Teknik Pengolahan Pangan dan Hasil Pertanian (TPPHP) Universitas Brawijaya Malang. Sedangkan, untuk pengujian profil asam lemak jenuh dan tak jenuh serta kandungan kolesterol dilakukan di Laboraturium Penelitian dan Pengujian Terpadu (LPPT) Universitas Gadjah Mada Yogyakarta.

Bahan baku yang digunakan adalah daging kelinci New Zealand White dengan jenis kelamin jantan, usia 3-4 bulan, berat hidup minimal $2 \mathrm{~kg}$ yang didapat dari Komunitas Kelinci Kediri (K3). Bahan pengikat dan bahan tambahan yang digunakan adalah tepung maizena, tepung roti, susu cair tanpa lemak, tepung terigu, telur ayam, bawang putih, merica bubuk, garam, dan gula pasir.

\section{Prosedur penelitian}

Penentuan formulasi nugget berdasarkan resep dari penelitian sebelumnya [9]. Perbandingan bahan formula nugget adalah sebagai berikut:

Tabel 1. Komposisi bahan per $100 \mathrm{~g}$ Nugget daging

\begin{tabular}{lc}
\multicolumn{2}{c}{ kelinci } \\
\hline Jenis Bahan & Berat $(\mathrm{g})$ \\
\hline Daging Kelinci & 30 \\
Telur Ayam & 29 \\
Tepung Roti & 18 \\
Tepung Maizena & 10 \\
Susu Cair tanpa Lemak & 6 \\
Tepung Terigu & 4 \\
\hline
\end{tabular}




\begin{tabular}{lc}
\hline \multicolumn{1}{c}{ Jenis Bahan } & Berat $(\mathrm{g})$ \\
\hline $\begin{array}{l}\text { Bumbu (bawang putih, } \\
\text { merica bubuk, garam, } \\
\text { gula pasir) }\end{array}$ & 3 \\
\hline Total & 100 \\
\hline
\end{tabular}

\section{Prosedur Sampling}

Dalam penelitian ini, kelinci yang didapatkan adalah berupa karkas sehingga tidak membutuhkan ethical clearance dalam penggunaannya. Karkas yang didapatkan kemudian difillet untuk diambil dagingnya. Daging yang digunakan adalah daging dari semua bagian yang terdapat pada karkas kelinci. Selanjutnya, daging kelinci fillet tersebut digiling menjadi satu untuk digunakan sebagai bahan pembuatan sampel nugget daging kelinci.

Desain penelitian dapat dilihat pada Gambar 1. berikut:

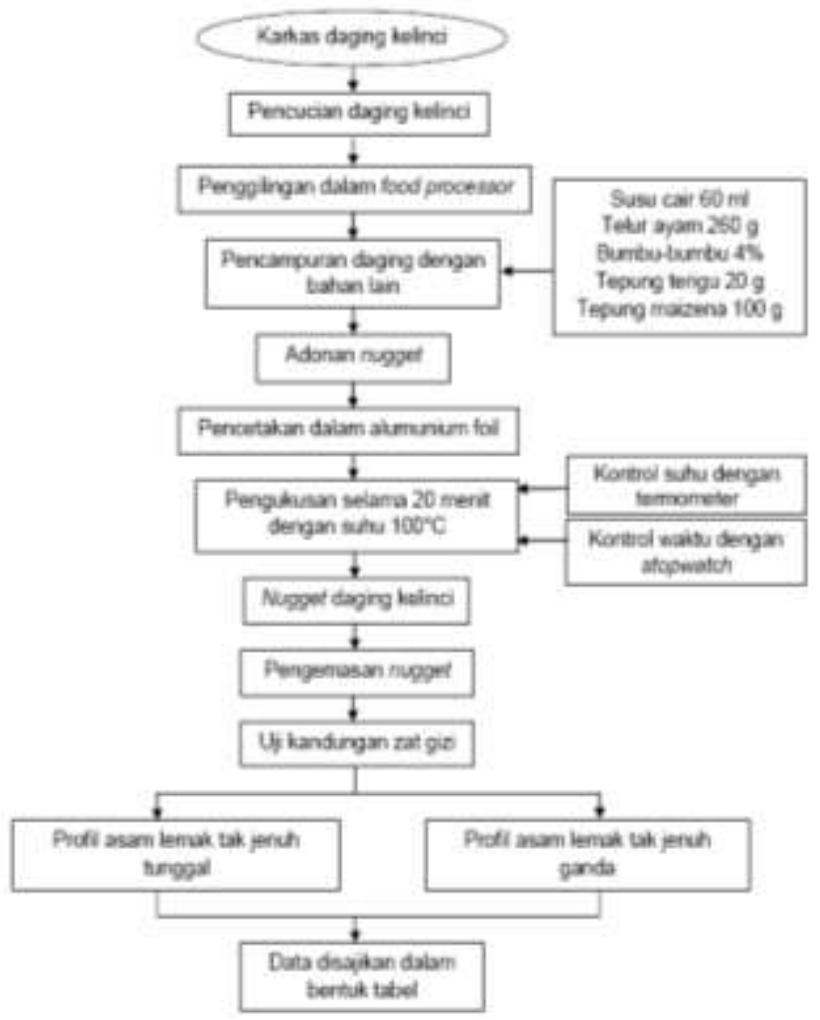

Gambar1. Bagan alur prosedur penelitian

\section{Prosedur Pengujian}

Penelitian ini diawali dengan pembuatan nugget, kemudian dilanjutkan dengan pengemasan vakum nugget dalam plastik jenis PE (Polyethylene). Nugget yang telah dikemas dalam plastik, dimasukkan ke dalam cool box yang telah diisi es (thermafreeze) dengan perbandingan es (thermafreeze) dan nugget $2: 1$ [13]. Setelah dikemas, dilakukan pengujian profil asam lemak jenuh dan tak jenuh serta kandungan kolesterol pada nugget daging kelinci tersebut.

\section{Pengujian Profil Asam Lemak Jenuh dan Tak Jenuh}

a. Persiapan dan Preparasi Sampel

1. Sampel nugget daging kelinci ditimbang sebanyak 20 gram.

2. Sampel dipotong-potong dalam ukuran kecil.

3. Sampel dikeringkan di dalam oven selama 24 jam pada suhu $90^{\circ} \mathrm{C}$.

4. Sampel yang sudah kering ditimbang dan dihaluskan.

5. Selanjutnya sampel dimasukkan ke dalam kertas saring yang dilapisi dengan kapas untuk persiapan ekstraksi [36].

b. Ekstraksi Lemak

1. Sampel dimasukkan ke dalam labu soxhlet, kemudian ditambahkan $100 \mathrm{ml}$ petroleum ether.

2. Ekstraksi dilakukan selama 24 jam, kemudian pelarut dibebaskan dari sampel dan dipekatkan dengan menggunakan oven pada suhu $50^{\circ} \mathrm{C}$ selama 2 jam dan ditimbang beratnya [36].

c. Metilasi Asam Lemak atau Pembentukan Metil Ester

1. Sampel ditimbang sebanyak 0,0298 gram dan dimasukkan ke dalam tabung bertutup Teflon.

2. Kemudian ditambahkan $1 \mathrm{~mL} \mathrm{NaOH} 0,5 \mathrm{~N}$ dalam methanol dan dipanaskan di atas penangas air pada suhu $80^{\circ} \mathrm{C}$ selama 20 menit.

3. Kemudian tabung diangkat dan didinginkan, setelah itu ditambahkan $\pm 2 \mathrm{~mL} \mathrm{BF3}$ dan dipanaskan pada suhu $80^{\circ} \mathrm{C}$ selama 20 menit, lalu didinginkan.

4. Selanjutnya ke dalam tabung ditambahkan 2 $\mathrm{mL} \mathrm{NaCl}$ jenuh dan $1 \mathrm{~mL}$ heksana, kemudian dikocok.

5. Lapisan heksana dipisahkan dengan pipet tetes dan dimasukkan ke dalam tabung yang berisi 0,1 gram $\mathrm{Na}_{2} \mathrm{SO}_{4}$ anhidrat, lalu didiamkan selama 15 menit.

6. Larutan sampel dipisahkan dengan vial dan siap untuk diinjeksikan [36].

d. Analisis Asam Lemak dengan Kromatografi Gas

1. Sebelum injeksi sampel ke dalam alat kromatografi gas, dilakukan conditioning alat sesuai standar dan jenis sampel yang akan diinjeksikan sebagai berikut: Kolom DEGS $10 \%$ dalam Chromosorb $2 \mathrm{~m} \times 1 / 8$ 
inci, laju aliran $\mathrm{N}_{2} 20 \mathrm{ml} / \mathrm{menit}$, laju aliran $\mathrm{H}_{2} 30 \mathrm{ml} /$ menit, laju aliran udara 200 $\mathrm{ml} / \mathrm{menit}$, suhu injektor $200^{\circ} \mathrm{C}$, suhu detektor $250^{\circ} \mathrm{C}$, suhu kolom $180^{\circ} \mathrm{C}$.

2. Kemudian pelarut diinjeksikan sebanyak 2 $\mu \mathrm{L}$ ke dalam kolom. Bila gas pembawa dan sistem pemanas sempurna, puncak pelarut akan terlihat dalam kurun waktu kurang dari 1 menit.

3. Setelah pena kembali ke garis nol (base line) kemudian larutan standar asam lemak diinjeksikan sebanyak $5 \mu \mathrm{L}$. Bila semua puncak standar telah keluar, maka waktu retensi (retention time) dan luas puncak dari masing-masing komponen akan terlihat.

4. Hasil kromatogram yang diperoleh dari kromatografi gas dianalisis dengan cara membandingkannya dengan kromatogram standar. Standar yang digunakan untuk asam lemak jenuh adalah Laurat, Miristat, Palmitat, dan Stearat, sedangkan untuk asam lemak tak jenuh adalah Oleat, Linoleat, dan Linolenat.

5. Konsentrasi tiap komponen asam lemak dapat dihitung dengan rumus berikut [36]:

Konsentrasi asam lemak $(\%)=\frac{\text { Luas area asam lemak }}{\text { Luas area total }- \text { Luas area pelarut }} \times 100 \%$

\section{Pengujian Kandungan Kolesterol}

1. Sampel nugget daging kelinci ditimbang dalam Erlenmeyer sebanyak 1 gram.

2. Kemudian ditambahkan $2 \mathrm{ml} \mathrm{KOH} 50 \%$, homogenkan, lalu tambahkan Etanol $95 \%$

3. Selanjutnya disaponifikasi pada suhu $80-100^{\circ} \mathrm{C}$ selama 15 menit.

4. Kemudian sampel didinginkan dengan air dan ditambahkan $10 \mathrm{ml}$ Toluene lalu kocok 10 detik.

5. Masukkan dalam corong pemisah tambahkan $10 \mathrm{ml} \mathrm{KOH} 1 \mathrm{M}$.

6. Tambahkan etanol $1 \mathrm{ml} \mathrm{95 \% .} \mathrm{Pisahkan,} \mathrm{buang}$ lapisan dibawah. Lalu tambahkan aquadest 10 $\mathrm{ml}$ lalu buang sisahkan lapisan di atas lakukan dua kali.

7. Masukkan campuran ekstrak pada tabung vakum. Kemudian 1 mikroliter diinjeksikan ke dalam gas kromatografi.

8. Recorder menghasilkan data berupa kurva setelah beberapa menit.

9. Data yang dihasilkan dibandingkan dengan standar kolesterol [37].

\section{Analisis Data}

Penelitian ini menggunakan sebanyak 3 kali pengulangan dengan sampel berupa nugget yang diformulasikan sesuai dengan penelitian sebelumnya [9].

\section{HASIL DAN PEMBAHASAN}

\section{Profil Asam Lemak Jenuh}

Hasil analisis profil asam lemak jenuh nugget daging kelinci pada sampel 1 sebesar $10,9 \%$, sampel 2 sebesar 21,9\%, dan sampel 3 sebesar 22,1\%. Ratarata hasil analisis profil asam lemak jenuh pada nugget daging kelinci adalah 18,4\% (Tabel2).

Tabel 2. Profil asam lemak jenuh pada Nugget daging kelinci

\begin{tabular}{|c|c|c|c|c|}
\hline \multirow{2}{*}{$\begin{array}{c}\text { Jenis Asam Lemak } \\
\text { Jenuh }\end{array}$} & \multicolumn{3}{|c|}{ Sampel (\%) } & \multirow{2}{*}{$\begin{array}{l}\text { Rata- } \\
\text { Rata }\end{array}$} \\
\hline & 1 & 2 & 3 & \\
\hline $\begin{array}{l}\text { 1. Asam } \\
\text { (C2:0) }\end{array}$ & $<0,1$ & $<0,1$ & $<0,1$ & $<0,1$ \\
\hline $\begin{array}{l}\text { 2. Asam Kaproat } \\
\text { (C4:0) }\end{array}$ & $<0,1$ & $<0,1$ & $<0,1$ & $<0,1$ \\
\hline $\begin{array}{l}\text { 3. Asam Kaprilat } \\
\text { (C6:0) }\end{array}$ & $<0,1$ & $<0,1$ & $<0,1$ & $<0,1$ \\
\hline $\begin{array}{l}\text { 4. Asam Kaprat } \\
\text { (C8:0) }\end{array}$ & $<0,1$ & $<0,1$ & $<0,1$ & $<0,1$ \\
\hline $\begin{array}{l}\text { 5. Asam } \\
\text { Undecanoik } \\
(\mathrm{C} 11: 0)\end{array}$ & $<0,1$ & $<0,1$ & $<0,1$ & $<0,1$ \\
\hline $\begin{array}{l}\text { 6. Asam Laurat } \\
(\mathrm{C} 12: 0)\end{array}$ & $<0,1$ & $<0,1$ & $<0,1$ & $<0,1$ \\
\hline $\begin{array}{l}\text { 7. Asam Tricanoik } \\
(\mathrm{C} 13: 0)\end{array}$ & $<0,1$ & $<0,1$ & $<0,1$ & $<0,1$ \\
\hline $\begin{array}{l}\text { 8. Asam Miristat } \\
(\mathrm{C} 14: 0)\end{array}$ & 1,77 & 0,47 & 0,67 & 0,97 \\
\hline $\begin{array}{l}\text { 9. Asam } \\
\text { Pentadecanoik } \\
\text { (C15:0) }\end{array}$ & $<0,1$ & $<0,1$ & $<0,1$ & $<0,1$ \\
\hline $\begin{array}{l}\text { 10. Asam Palmitat } \\
\text { (C16:0) }\end{array}$ & 5,19 & 9,07 & 10,3 & 8,21 \\
\hline $\begin{array}{l}\text { 11. Asam Margarik } \\
\text { (C17:0) }\end{array}$ & 0,24 & 0,36 & 0,58 & 0,39 \\
\hline $\begin{array}{l}\text { 12. Asam Stearat } \\
\text { (C18:0) }\end{array}$ & $<0,1$ & $<0,1$ & $<0,1$ & $<0,1$ \\
\hline $\begin{array}{l}\text { 13. Asam Arakhidat } \\
\text { (C20:0) }\end{array}$ & $<0,1$ & $<0,1$ & $<0,1$ & $<0,1$ \\
\hline $\begin{array}{l}\text { 14. Asam } \\
\text { Heneicosanoik } \\
\text { (C21:0) }\end{array}$ & $<0,1$ & $<0,1$ & $<0,1$ & $<0,1$ \\
\hline $\begin{array}{l}\text { 15. Asam Benehik } \\
\text { (C22:0) }\end{array}$ & 2,7 & 7,45 & 7,70 & 5,95 \\
\hline
\end{tabular}




\begin{tabular}{|c|c|c|c|c|}
\hline \multirow{2}{*}{$\begin{array}{c}\text { Jenis Asam } \\
\text { Lemak Jenuh }\end{array}$} & \multicolumn{3}{|c|}{ Sampel (\%) } & \multirow{2}{*}{$\begin{array}{l}\text { Rata- } \\
\text { Rata }\end{array}$} \\
\hline & 1 & 2 & 3 & \\
\hline \multicolumn{5}{|l|}{ 16. Asam } \\
\hline $\begin{array}{l}\text { Tricosanoik } \\
(\mathrm{C} 23: 0)\end{array}$ & $<0,1$ & $<0,1$ & $<0,1$ & $<0,1$ \\
\hline \multirow{2}{*}{$\begin{array}{l}\text { 17. Asam } \\
\text { Lignoserik } \\
\text { (C24:0) }\end{array}$} & 1,03 & 4,63 & 2,86 & 2,84 \\
\hline & & & & \\
\hline Total & 10,9 & 21,9 & 22,1 & $18 ., 4$ \\
\hline
\end{tabular}

Profil Asam Lemak Tak Jenuh Tunggal

Hasil analisis profil asam lemak tak jenuh tunggal nugget daging kelinci pada sampel 1 sebesar 34,4\%, sampel 2 sebesar 30,2\%, dan sampel 3 sebesar $37,9 \%$. Rata-rata hasil analisis profil asam lemak tak jenuh tunggal pada nugget daging kelinci adalah $34,1 \%$ (Tabel 3).

Tabel 3 Profil asam lemak tak jenuh tunggal pada

Berdasarkan hasil analisis laboratorium dari 17 jenis asam lemak jenuh yang dianalisis, terdapat 12 jenis diantaranya memiliki hasil $<0,1 \%$, hal tersebut salah satunya dipengaruhi oleh panjang rantai asam lemak jenuh, dimana semakin pendek rantai asam lemak jenuh maka asam lemak jenuh tersebut akan semakin mudah rusak akibat paparan panas [14].

Profil asam lemak jenuh tertinggi adalah asam palmitat $8,21 \%$. Asam palmitat merupakan asam lemak jenuh yang dapat ditemukan dalam makanan seperti daging-dagingan dan dairy product (50$60 \%)$, cocoa butter (26\%), dan olive oil (8-20\%) [15]. Meskipun sering dianggap memiliki efek buruk pada penyakit kronis pada orang dewasa, asam palmitat menjadi komponen penting dari membran sel, sekresi dan transportasi lipid [16]. Asam behenik ditemukan pada nugget daging kelinci sebesar $5,95 \%$. Asam behenik yang tergolong dalam asam lemak jenuh rantai panjang telah dicurigai menjadi komponen terpenting dalam peningkatan kolesterol di dalam tubuh [17].

Profil asam lemak jenuh selanjutnya yang terdapat pada nugget daging kelinci yaitu asam lignoserat sebesar 2,84\%. Pada nugget ikan kakap merah ditemukan asam lignoserat sebesar 0,23\% [18]. Perbandingan kandungan asam lignoserat pada nugget daging kelinci lebih tinggi daripada nugget ikan kakap merah.

Asam margarik menjadi profil asam lemak jenuh yang terendah dengan hasil $0,39 \%$. Pada daging kelinci New Zealand White juga ditemukan asam margarik sebeasr 0,51\% [19]. Nugget daging kelinci memiliki kandungan asam lemak margarik lebih rendah dibandingkan dengan daging kelinci segar disebabkan karena penggunaan daging kelinci pada pembuatan nugget hanya sebanyak $30 \mathrm{~g}$ atau $30 \%$ dari seluruh berat bahan. Pada nugget daging kelinci telah ditambahkan beberapa bahan pengisi nugget seperti telur, tepung, dan susu, sehingga nugget tidak sepenuhnya menggunakan daging kelinci. nugget daging kelinci

\begin{tabular}{|c|c|c|c|c|}
\hline \multirow{3}{*}{$\begin{array}{c}\text { Jenis Asam } \\
\text { Lemak Tak Jenuh } \\
\text { Tunggal }\end{array}$} & \multirow{2}{*}{\multicolumn{3}{|c|}{ Sampel (\%) }} & \multirow{3}{*}{$\begin{array}{l}\text { Rata- } \\
\text { Rata }\end{array}$} \\
\hline & & & & \\
\hline & 1 & 2 & 3 & \\
\hline $\begin{array}{ll}\text { 1. } & \text { Asam } \\
\text { Miristoleat } \\
(\mathrm{C} 14: 1)\end{array}$ & $<0,1$ & $<0,1$ & $<0,1$ & $<0,1$ \\
\hline $\begin{array}{l}\text { 2. Asam Cis-10- } \\
\text { Pentadekanoat } \\
\text { (C15:1) }\end{array}$ & $<0,1$ & $<0,1$ & $<0,1$ & $<0,1$ \\
\hline $\begin{array}{l}\text { 3. Asam } \\
\text { Palmitoleat } \\
\text { (C16:1) }\end{array}$ & 0,86 & 0,57 & 0,71 & 0,71 \\
\hline $\begin{array}{l}\text { 4. Asam Cis-10- } \\
\text { Heptadekanoat } \\
\text { (C17:1) }\end{array}$ & $<0,1$ & $<0,1$ & $<0,1$ & $<0,1$ \\
\hline $\begin{array}{l}\text { 5. Asam Trans-9- } \\
\text { Elaidat } \\
\text { (C18:1n9t) }\end{array}$ & 3,23 & 5,76 & 4,73 & 4,57 \\
\hline $\begin{array}{l}\text { 6. Asam Oleat } \\
(\mathrm{C} 18: 1 \mathrm{n} 9 \mathrm{c})\end{array}$ & 12,96 & 12,67 & 14,98 & 13,5 \\
\hline $\begin{array}{l}\text { 7. Asam Cis-11- } \\
\text { Eikosanoat } \\
\text { (C20:1) }\end{array}$ & $<0,1$ & $<0,1$ & $<0,1$ & $<0,1$ \\
\hline $\begin{array}{l}\text { 8. Asam Erukat } \\
(\mathrm{C} 22: 1 \mathrm{n} 9)\end{array}$ & 8,78 & 3,33 & 10,45 & 7,52 \\
\hline $\begin{array}{ll}\text { 9. } & \text { Asam } \\
\text { Nervonat } \\
\text { (C24:1) }\end{array}$ & 8,58 & 7,95 & 7,05 & 7,86 \\
\hline Total & 34,4 & 30,2 & 37,9 & 34,1 \\
\hline
\end{tabular}

Berdasarkan hasil analisis laboratorium didapati profil asam lemak tak jenuh tunggal pada nugget daging kelinci yaitu asam oleat sebesar 13,5\%. Asam oleat merupakan lemak baik yang bermanfaat bagi tubuh yaitu untuk menurunkan kadar kolesterol dan juga memiliki kemampuan untuk meningkatkan kolesterol HDL yang dapat menurunkan risiko terjadinya penyakit jantung [20].

Asam nervonat ditemukan juga dalam hasil analisis profil asam lemak tak jenuh tunggal sebesar 7,86\%. Asam nervonat merupakan salah satu komponen inti dari sel-sel saraf otak dan jaringan saraf yang bermanfaat bagi kesehatan otak. Asam nervonat memiliki kemampuan untuk memperbaiki jalur saraf 
otak yang rusak dan mempromosikan regenerasi selsel saraf baru yang berperan efektif dalam pengobatan skizofrenia, psikosis, dan alkoholisme [21].

Profil asam lemak lain yang juga terdapat pada nugget daging kelinci adalah asam erukat. Kandungan asam erukat pada nugget daging kelinci sebesar 7,52\%. Asam erukat merupakan asam lemak tak jenuh tunggal rantai panjang [22]. Konsumsi asam erukat dalam jumlah tinggi untuk jangka waktu panjang dapat meningkatkan risiko terjadinya nekrosis miokard [23]. Anjuran konsumsi asam erukat dalam sehari adalah maksimal 5\% dari total energi [21].

Pada nugget daging kelinci juga ditemukan adanya kandungan asam lemak trans 9 elaidat sebesar 4,57\%. Asam Lemak Trans (ALT) terbentuk karena adanya beberapa proses perlakuan terhadap suatu asam lemak yang memiliki ikatan rangkap [24]. Keberadaan ikatan rangkap dalam struktur asam lemak mengakibatkan adanya perbedaan konfigurasi, yaitu konfigurasi cis bila ikatan rangkapnya terletak pada sisi yang sama dengan gugus hidrogen dan konfigurasi trans apabila ikatan rangkapnya terletak di sisi yang berlawanan [25]. Perubahan cis menjadi trans mulai terjadi pada pemanasan dengan temperatur $180^{\circ} \mathrm{C}-250^{\circ} \mathrm{C}$ [26].

Selanjutnya, ditemukan juga adanya kandungan asam palmitoleat sebesar $0,71 \%$ pada nugget daging kelinci. Perbandingan kandungan asam palmitoleat antara nugget daging kelinci dengan nugget ikan nike $(0,68 \%)$ [27], didapatkan hasil bahwa kandungan asam palmitoleat sedikit lebih tinggi pada nugget daging kelinci. Asam palmitoleat memiliki beberapa manfaat bagi kesehatan. Salah satunya adalah untuk menurunkan risiko terjadinya penyakit Non Alcoholic Fatty Liver Disease (NAFLD) melalui perannya yaitu menurunkan lipogenesis di hati. Selain itu, asam palmitoleat juga berperan untuk penyakit kardiovaskular melalui penurunan kadar trigliserida dan kolesterol LDL, serta mampu meningkatkan kadar HDL dalam darah [28].

\section{Profil Asam Lemak Tak Jenuh Ganda}

Hasil analisis profil asam lemak tak jenuh ganda nugget daging kelinci pada sampel 1 sebesar 20,5\%, sampel 2 sebesar 22,9\%, dan sampel 3 sebesar $20,2 \%$. Rata-rata hasil analisis profil asam lemak tak jenuh ganda pada nugget daging kelinci adalah $21,2 \%$ (Tabel 4).
Tabel 4. Profil asam lemak tak jenuh ganda pada nugget daging kelinci

\begin{tabular}{|c|c|c|c|c|}
\hline \multirow{2}{*}{$\begin{array}{c}\text { Jenis Asam } \\
\text { Lemak Tak } \\
\text { Jenuh Ganda }\end{array}$} & \multicolumn{3}{|c|}{ Sampel (\%) } & \multirow[t]{2}{*}{$\begin{array}{l}\text { Rata- } \\
\text { Rata }\end{array}$} \\
\hline & 1 & 2 & 3 & \\
\hline $\begin{array}{l}\text { Asam } \\
\text { Linolelaidat } \\
\text { (C18:2n9t) }\end{array}$ & $<0,1$ & $<0,1$ & $<0,1$ & $<0,1$ \\
\hline $\begin{array}{l}\text { 2. Asam } \\
\text { Linoleat } \\
\text { (C18:2n6) }\end{array}$ & 12,76 & 13,73 & 12,80 & 13,09 \\
\hline $\begin{array}{l}\text { 3. Asam } \gamma- \\
\text { Linolenat } \\
\text { (C18:3n6) }\end{array}$ & $<0,1$ & $<0,1$ & $<0,1$ & $<0,1$ \\
\hline $\begin{array}{l}\text { 4. Asam } \\
\text { Linolenat } \\
\text { (C18:3n3) }\end{array}$ & $<0,1$ & $<0,1$ & $<0,1$ & $<0,1$ \\
\hline $\begin{array}{l}\text { 5. Asam Cis- } \\
\text { 11-14- } \\
\text { Eikosadieno } \\
\text { at (C20:2) }\end{array}$ & $<0,1$ & $<0,1$ & $<0,1$ & $<0,1$ \\
\hline $\begin{array}{l}\text { 6. Asam Cis-8- } \\
\text { 11-14- } \\
\text { Eikosatrieno } \\
\text { at (C20:3n6) }\end{array}$ & 0,11 & $<0,1$ & $<0,1$ & 0,03 \\
\hline $\begin{array}{l}\text { 7. Asam Cis- } \\
\text { 11-14-17- } \\
\text { Eikosatrieno } \\
\text { at (C20:3n3) }\end{array}$ & $<0,1$ & $<0,1$ & $<0,1$ & $<0,1$ \\
\hline $\begin{array}{ll}\text { 8. } & \text { Asam } \\
\text { Arakidonat } \\
\text { (C20:4n6) }\end{array}$ & $<0,1$ & $<0,1$ & $<0,1$ & $<0,1$ \\
\hline $\begin{array}{l}\text { 9. Asam Cis- } \\
\text { 13-16- } \\
\text { Dokosadieno } \\
\text { at (C22:2) }\end{array}$ & $<0,1$ & $<0,1$ & $<0,1$ & $<0,1$ \\
\hline $\begin{array}{l}\text { 10. EPA } \\
\text { (C20:5n3) }\end{array}$ & 1,49 & 4,35 & 1,64 & 2,49 \\
\hline $\begin{array}{l}\text { 11. DHA } \\
\text { (C22:6n3) }\end{array}$ & 6,17 & 4,90 & 5,79 & 5,62 \\
\hline Total & 20,5 & 22,9 & 20,2 & 21,2 \\
\hline
\end{tabular}

Berdasarkan hasil analisis laboratorium didapati profil asam lemak tak jenuh ganda pada nugget daging kelinci yaitu asam linoleat sebesar 13,09\%. Apabila dibandingkan dengan daging kelinci segar $(17,9 \%)$ [29], kandungan asam linoleat pada nugget daging kelinci lebih rendah. Adanya perbedaan kandungan tersebut disebabkan karena pada pembuatan nugget hanya menggunakan $30 \%$ daging kelinci dari total bahan dengan berat \pm 30 gram yang dicampur dengan bahan lain seperti telur ayam, tepung-tepungan, bumbu, dan susu tanpa lemak. Kandungan asam linoleat yang berbeda ini juga dapat disebabkan karena adanya proses pengukusan 
pada saat pembuatan nugget. Pengurangan asam lemak bisa disebabkan karena pengurangan keseluruhan kandungan lemak dari sampel yang diperiksa [30]. Terjadinya penurunan kadar lemak setelah proses pengukusan disebabkan karena sifat lemak yang tidak tahan panas [31].

Asam linoleat memiliki beberapa manfaat diantaranya adalah untuk mencegah kerusakan jaringan kulit, membantu dalam transport dan metabolisme kolesterol sehingga dapat menurunkan kadar kolesterol darah, serta merupakan prekursor komponen aktif prostaglandin yang dibutuhkan dalam semua jaringan tubuh dan aktivitasnya mempengaruhi pembekuan darah dan fungsi jantung [20].

Selain asam linoleat, pada nugget daging kelinci juga ditemukan profil asam lemak tak jenuh ganda lain yakni EPA dan DHA masing-masing sebesar 2,49\% dan 5,62\%. Manfaat dari EPA dan DHA adalah dapat menurunkan risiko terjadinya penyakit jantung koroner [32]. Konsumsi EPA dan DHA dalam jangka waktu panjang pada penderita penyakit jantung terbukti mampu menurunkan risiko kematian mendadak hingga $45 \%$ jika dibandingkan dengan penderita yang tidak mengkonsumsi EPA dan DHA [33]. Hal tersebut berkaitan karena EPA dan DHA bermanfaat untuk menurunkan kadar LDL, meningkatkan kadar HDL, berperan sebagai anti inflamasi, serta dapat mencegah timbulnya platelet darah. Platelet darah dalam jumlah besar akan mengganggu aliran darah yang merupakan faktor utama penyebab serangan jantung dan stroke [20][33].

\section{Kandungan Kolesterol}

Hasil analisis kandungan kolesterol nugget daging kelinci pada sampel 1 sebesar $15,3 \%$, sampel 2 sebesar 12,3\%, dan sampel 3 sebesar 17,6\%. Ratarata hasil analisis kandungan kolesterol pada nugget daging kelinci adalah 15,1 mg/100g (Tabel5).

Tabel 5. Kandungan kolesterol pada nugget daging kelinci

\begin{tabular}{ccccc}
\hline \multirow{2}{*}{ Parameter } & \multicolumn{3}{c}{ Sampel $(\mathrm{mg} / 100 \mathrm{~g})$} & \multirow{2}{*}{$\begin{array}{c}\text { Rata- } \\
\text { Rata }\end{array}$} \\
\cline { 2 - 4 } & 1 & 2 & 3 & 15,1 \\
\hline Kolesterol & 15,3 & 12,3 & 17,6 & 15 \\
\hline
\end{tabular}

Berdasarkan hasil analisis kandungan kolesterol yang telah dilakukan di laboratorium didapati hasil rata-rata yaitu $15,1 \mathrm{mg} / 100$ g. Hasil tersebut tergolong lebih rendah jika dibandingkan dengan nugget ayam sebesar 19,93 mg/100 g. Kandungan kolesterol pada nugget daging kelinci telah mendapatkan kontribusi bahan lain yang juga memiliki kandungan kolesterol yaitu telur ayam. Telur ayam memiliki kandungan kolesterol sebesar $329 \mathrm{mg} / 100 \mathrm{~g}$ bahan [34], dimana berat telur yang digunakan dalam pembuatan nugget daging kelinci sebanyak $29 \mathrm{~g}$ atau sebesar $29 \%$ yang mengandung $11,34 \mathrm{mg} / 100 \mathrm{~g}$ kolesterol. Selain itu, proses pengolahan atau pemasakan menggunakan panas dan uap air mendidih dalam suhu $100^{\circ} \mathrm{C}$ selama 20 menit juga dapat mempengaruhi kandungan dan struktur kolesterol pada nugget daging kelinci. Panas menyebabkan kolesterol larut bersamaan dengan terlepasnya air dari bahan [18].

Kolesterol memerankan peranan penting bagi kesehatan tubuh, dimana kolesterol dapat memberikan dampak yang baik (HDL) dan juga buruk bagi kesehatan (LDL). Jika serum LDL ditemukan tinggi pada darah maka akan meningkatkan potensi pembentukan plaque pada dinding pembuluh darah. Pembentukan plaque pada dinding pembuluh darah menyebabkan arteri menjadi menebal, mengeras, dan mengurangi kelenturan, memperlambat aliran darah hingga dapat menghambat aliran darah ke jantung hingga terjadi angina (nyeri pada dada) yang merupakan tanda awal dari penyakit jantung [35].

Berdasarkan hasil analisis data diatas, dapat diketahui bahwa pada nugget daging kelinci mengandung beberapa profil asam lemak jenuh, asam lemak tak jenuh, baik tunggal maupun ganda, dan kolesterol yang memiliki manfaat bagi kesehatan sekaligus dampak buruk apabila dikonsumsi dalam jumlah yang berlebihan, terutama untuk penyakit jantung koroner. Hal tersebut berkaitan dengan kemampuan dari masing-masing asam lemak jenuh dan kandungan kolesterol yang dapat meningkatkan kadar LDL serta asam tak jenuh yang mampu untuk menurunkan kadar LDL dan meningkatkan kadar HDL.

Oleh karena itu, dengan mempertimbangkan kedua hal tersebut anjuran konsumsi nugget daging kelinci dalam penelitian ini yaitu sebanyak 65 gram atau \pm 3 potong nugget dalam sehari. Nugget daging kelinci dengan berat 65 gram $( \pm 3$ potong nugget) mengandung beberapa zat gizi yaitu karbohidrat sebesar $19,6 \%$, protein $6,9 \%$, dan lemak total $2,1 \%$ [9]. Selain itu, pada nugget daging kelinci juga mengandung total asam lemak jenuh $11,69 \%$, total kandungan kolesterol 9,8\%, serta beberapa profil asam lemak tak jenuh yaitu asam oleat $8,77 \%$, asam nervonat $5,1 \%$, asam erukat $4,88 \%$, asam trans 9 
elaidat $2,97 \%$, asam palmitoleat $0,46 \%$, asam linoleat $8,5 \%$, DHA 3,65\%, dan EPA $1,61 \%$.

\section{KESIMPULAN}

Nugget daging kelinci mengandung 17 jenis asam lemak jenuh dengan kandungan tertinggi pada asam palmitat $8,21 \%$. Selain itu terdapat 9 jenis asam lemak tak jenuh tunggal dengan kandungan tertinggi asam oleat sebesar 13,5\% dan 11 jenis asam lemak tak jenuh ganda dengan kandungan tertinggi yaitu asam linoleat sebesar 13,09\%. Kandungan kolesterol pada nugget daging kelinci adalah sebesar 15,1 $\mathrm{mg} / 100 \mathrm{~g}$.

\section{UCAPAN TERIMAKASIH}

Penelitian ini didukung oleh Komunitas Kelinci Kediri (K3) atas pembiayaan dan penyediaan daging kelinci selama penelitian berlangsung.

\section{REFERENSI}

[1] $\mathrm{M}$ Yanis; $\mathrm{S}$ Aminah; $\mathrm{Y}$ Handayani; $\mathrm{T}$ Ramadhan, "Karakteristik Produk Olahan Berbasis Daging Kelinci," Buletin Pertanian Perkotaan, vol. 6, no. 2, 2016.

[2] C S Mas'ud; Y R L Tulung; J Umboh; Y R L Rahaasia, "Pengaruh Pemberian Beberapa Jenis Hijauan Terhadap Performans Ternak Kelinci," Jurnal zootek, vol. 35 , no. 02, 2015.

[3] Kementerian Pertanian RI, Statistik Peternakan dan Kesehatan Hewan, Jakarta: Direktorat Jenderal Peternakan dan Kesehatan Hewan, 2018.

[4] B. Sarwono, Kelinci Potong dan Hias (Revisi), Jakarta: Agromedia Pustaka, 2006.

[5] D. Z. A and S. Z, "The role of rabbit meat as fuctional food," Meat Sci, vol. 88, no. 3, 2011.

[6] E. V. Arnyke, D. Rosyidi and L. E. Radiati, "Peningkatan potensi pangan fungsional naget daging kelinci dengan substitusi wheat bran, pollard dan rumput laut," Jurnal Ilmu-Ilmu Peternakan, vol. 24, no. 1, pp. 56-71, 2001.

[7] E. Marhaeniyanto and S. Susanti, "Penggunaan Konsentrat Hijau untuk Meningkatkan Produksi Ternak Kelinci New Zealand White," Jurnal Ilmu Ilmu Peternakan, vol. 27, no. 1, 2017.

[8] I. Yuanita and L. Silitonga, "Sifat Kimia dan Palatabilitas Nugget Ayam Menggunakan Jenis dan Konsentrasi Bahan Pengisi yang
Berbeda," Jurnal Ilmu Hewani Tropika (Journal Tropical Animal Science), vol. 3, no. 1, 2014.

[9] R. M. Widyanto, T. S. Kusuma, A. L. Hasinofa, A. P. Zetta, F. I. V. B. Silalahi and R. W. Safitri, "Analisa Zat Gizi, Kadar Asam Lemak, serta Komponen Asam Amino Nugget Daging Kelinci New Zealand White (Oryctolagus cuniculus)," Jurnal AL-AZHAR INDONESIA SERI SAINS DAN TEKNOLOGI, vol. 4, no. 3, 2018.

[10] WHO, "Noncommunicable Diseases (NCD) Country Profiles of Indonesia," 2014.

[11] Kementrian Kesehatan RI, "Riset Kesehatan Dasar," Badan Penelitian dan Pengembangan Kesehatan , Jakarta, 2013.

[12] WHO, "Reducing Risks, Promoting Healty Life, Geneva," 2002.

[13] Uju, "Pengaruh Penyimpanan Beku Surimi Terhadap Mutu Bakso Ikan Jangilus (istiophorus sp)," Buletin Teknologi Hasil Perikanan, vol. IX, no. 2, 2006.

[14] R. A. D. Sartika, "Pengaruh Asam Lemak Jenuh, Tidak Jenuh dan Asam Lemak Trans Terhadap Kesehatan," Jurnal Kesehatan Masyarakat Nasional, vol. 2, no. 4, 2008.

[15] SM Innis, "Palmitic Acid in Early Human Development," Crit Rev Food Sci Nutr, vol. 56, no. 12, 2016.

[16] C. Agostoni, L. Moreno and R. Shamir, "Palmitic Acid and Health: Introduction," Critical Reviews in Food Science and Nutritions, vol. 56, no. 12, pp. 1941-1942, 2016.

[17] C. B. Nilo and D. A. Margo, "Behenic acid is a cholesterol-raising saturated fatty acid in humans," American Society for Nutrition, vol. 73, pp. 41-44, 2001.

[18] A. Saraswati, "Efek Pengukusan Terhadap Kandungan Asam Lemak dan Kolesterol Kakap Merah (Lutjanus bohar) [Skripsi]," Fakultas Perikanan dan Ilmu Kelautan, ITB, Bandung, 2013.

[19] T. H. L. d. Andrade, L. A. F. Pascoal and et all, "Performance, fatty acids profile and oxidative stability of meat of rabbits fed different lipid sources," Food Science and Technology, vol. 38, no. 1, 2018.

[20] D. M. Utari, "Kandungan Asam Lemak, Zink dan Copper Pada Tempe, Bagaimana Potensinya untuk Mencegah Penyakit Degenaratif," Gizi Indon, vol. 33, no. 2, pp. 108-115, 2010.

[21] Q. Qiao, X. Wang, H. Ren, K. An, Z. Feng, T. Cheng and Z. Sun, "Oil Content and Nervonic 
Acid Content of Acer truncatum Seeds from 14 Regions in China," Horticultural Plant Journal, vol. 5, no. 1, pp. 24-30, 2019.

[22] N. H. Sissener, R. Ørnsrud, M. Sanden, L. Frøyland, S. Rem $\varnothing$ and a. A.-K. Lundebye, "Erucic Acid (22:1n-9) in Fish Feed, Farmed, and Wild Fish and Seafood Products," Nutrients, vol. 10, no. 10, 2018.

[23] H. K. Knutsen, J. Alexander, L. Barregård, M. Bignami, B. Brüschweiler and et all, "Erucic acid in feed and food," EFSA Journal, vol. 14, no. 11, 2016.

[24] I. T. Maulana, "Pemisahan Asam Elaidat (Trans -9-Octadecenoic Acid) Dan Asam Lemak Jenuh Serta Peningkatan Kandungan ESPA Dan DHA Dari Minyak Limbah Perusahaan Pengolahan Ikan [Tesis]," Institut Teknologi Bandung, Bandung, 2013.

[25] A. A Suryani, "Komposisi Asam Lemak Dan Kolesterol Belut Sawah (Monopterus Albus) Akibat Penggorengan. [Skripsi]," Fakultas Perikanan dan Ilmu Kelautan Institut Pertanian Bogor, Bogor, 2012.

[26] J. Silalahi and S. D. R. Tampubolon, "Asam Lemak Trans Dalam Makanan Dan Pengaruhnya Terhadap Kesehatan," Jurnal Teknologi dan Industri Pangan, vol. 13, no. 2, 2002.

[27] S. A. Liputo, S. Berhimpon and F. Fatimah, "Analisa Nilai Gizi Serta Komponen Asm Amino dan Asam Lemak dari Nugget Ikan Nike (Awaous Melanocephalus) dengan Penambahan Tempe," Chemistry Progess, vol. 6, no. 1, 2013.

[28] M.E Frigolet; R.G Anguilar, "The Role of The Novel Lipokine Palmitoleic Acid in Health and Disease," Advances in Nutritions, vol. 8, no. $1,2017$.
[29] F Lebas; P Coudert; H. D. Rochambeau dan R.G Thebault, The Rabbit Husbandry, Health And Procutio, Rome: Food And Agriculture Organization of The United Nations, 1997.

[30] Asmaa, Zzaman and d. Tajul, "Effect on Superheated Steam Cooking on Fat And Fatty Acid Composition of Sausage," Internasional Food Research Journal, vol. 22, no. 2, 2015.

[31] C. Anwar, Irhami and M. Kemalawaty, "Pengaruh Jenis Ikan dan Metode Pemasakan terhadap Mutu Abon Ikan," Jurnal FistechJurnal Teknologi Hasil Perikanan, vol. 7, no. 2, 2018

[32] I. T. Maulana, G. Reyhan, P.Sani Ega and K. Reza A, "Pengaruh Pemberian Mikroemulsi Limbah Minyak Terhadap Kandungan Asam Lemak Omega -3 Di Dalam Telur," ETHOS: Jurnal Penelitian dan Pengabdian, vol. 5, no. 2, 2017.

[33] W. S. Haris, "Fish oil supplementation: Evidence for health benefits," Cleveland Clinic Journal of Medicine, vol. 5, no. 2, 2017.

[34] M. Saidin, "Kandungan Kolesterol Dalam Berbagai Bahan Makanan Hewani," Buletin Penelitian Kesehatan, vol. 27, no. 2, 2000.

[35] H. Ma and K.-J. Shieh, "Cholesterol and Human Health," The Journal of American Science, vol. 2, no. 1, 2006.

[36] Susilawati, Murhadi, dan Agustina, "Ragam Asam-Asam Lemak Daging Kambing Dan Sapi Segar Serta Olahannya Pada Lokasi Karkas Yang Berbeda," Prosiding Seminar Agroindustri dan Lokakarya Nasional FKPTTPI, pp. 2-3, 2015.

[37] M. Yasser, "Identifikasi Kandungan Kolesterol pada Udang Kelong Basah Menggunakan Metode Gas ChromatographyMass Spectroscopy (GC-MS)," Jurnal Informasi Teknologi, vol. 4, no. 1, pp. 49-52, 2017. 